\title{
Analysis of an SME using Silicon and Flexible Organic Solar Cells as Replacements for Fossil Fuel Sources of Electricity in UK and Iraq
}

\author{
Azad Azabany ${ }^{1}$, Ari Azabanee ${ }^{1}$, Khalid Khan ${ }^{2}$, Mahmood Shah ${ }^{1}$ and Waqar Ahmed ${ }^{3}$ \\ 1. Lancashire Business School, University of Central Lancashire, Preston PR1 2HE, United Kingdom \\ 2. School of Engineering, University of Central Lancashire, Preston PR1 2HE, United Kingdom \\ 3. School of Medicine, University of Central Lancashire, Preston PR1 2HE, United Kingdom
}

\begin{abstract}
Currently, 86\% of the energy originates from fossil fuelsforelectricity. These are expected to run out, causing severe environmental damage threatening future generations. The total impact of Small and Medium Enterprises (SMEs) on the economy is significant. Solar cells harness the sun's energy to generate electricity in an environmentally friendly manner. This study compares silicon solar cells to flexible Organic Photovoltaic solar cells (OPV) for electricity energy for a micro-business in the UK and Iraq. It shows that it is feasible to replace existing fossil fuel sources with solar cells in Iraq due to a greater amount of solar radiation striking the earth's surface. Flexible solar cells can replace a proportion of the energy requirements in the UK and a larger proportion in Iraq. Using existing 20\% efficient solar cells, $28 \%$ and $83 \%$ of the energy requirements of the microbusiness can be replaced in UK and Iraq respectively. Assuming 20\% efficiency for solar cells placed on windows, $74 \%$ and $220 \%$ of the energy requirements of UK and Kurdistan can be replaced respectively and the surplus stored.
\end{abstract}

Key words: Energy management, silicon solar cells, flexible organic solar cells, $\mathrm{CO}_{2}$ emissions, Iraq, United Kingdom.

\section{Introduction}

Fossil fuels are finite and with increasing demand will run out with dire consequences on the economy, lifestyle and transportation [1]. The crisis needs to be overcome urgently and new sources of energy developed to replace existing sources. The Middle East represents $5 \%$ of the world's population but has about $66 \%$ of world's oil reserves and $43 \%$ of world gas reserves [2]. Some Middle Eastern countries are rich, however, the wealth is unevenly distributed and does not always lead to a widespread economic development [3]. Currently, the majority of businesses deriveenergy from non-renewable fossil fuel sources. A major problem with this resource is major environmental problems associated with climate change arising due to rapidly increasing demand from

Corresponding author: Waqar Ahmed, Ph.D., research field: nanotechnology. population growth, increased lifespan, global warming causing ice caps to melt, rising sea levels, flooding and depletion of the ozone layer. Numerous studies have focused on large distributors, manufacturing companies and domestic users. However, very studies have focused on SMEs particularly in the service sector. There are a large number of SMEs in UK and Iraq and their combined impactsare massive.

Previously, an analysis of a number of small service businesses in terms of its energy utilization and $\mathrm{CO}_{2}$ generation has been presented [4]. The feasibility of replacing fossil fuels sources of electricity with flexible organic solar energy from the sun has been investigated and a comparison was made between UK and Iraq assuming an efficiency of $20 \%$.

Research and development shows promise in developing new generation of solar cells such as flexible organic solar cells [5]. Latest nanotechnologies will improve the efficiency, reliability and application 
of solar cells, making it feasible to replace the existing fossil fuels energy sources with new generation of solar cells, which have much higher efficiencies and reliability. Flexible solar cells would be less intrusive, cheaper than silicon solar cells, more efficient and widely applicable [6]. Silicon solar cells also have the disadvantage of degrading over time and thus need to be replaced.

\section{Background}

To meet the demand for renewable energy, the photovoltaic sector has experienced exponential growth over the last few years. In 2004, over $90 \%$ of this emerging market was dominated by wafer-based crystalline silicon technology. New technologies are being developed and forecast to enter the market in the near future. One of these promising alternatives is an organic solar cell. Though still lacking behind in conversion efficiency, they exhibit several advantages over established technologies. Among these are the potential of cheap processing on large areas, possible semi-transparency,mechanical flexibility and very light weight [7]. In conventional solar panels, the supporting structures of the panel like glass, brackets etc. are twice as costly as the photovoltaic materials manufactured on them. As paper costs approximately a thousandth of glass, solar cells using printing processes can be much cheaper than conventional solar panels. Other methods involving coating paper with materials include first coating the paper with a smooth material to counteract the molecular scale roughness of paper. But in this method, the photovoltaic material can be coated directly onto untreated paper [7].

Traditional inorganic Si-PVs convert 25\% of sun energy to electricity with an average life span of twenty years, but are costly and complicated to manufacture. Currently, Si-PVs account for $13 \%$ of market share in the global renewable energy sector and $3 \%$ of the total global energy generation sector [8]. Thin film PVs such as OPVs are only able to convert $8 \%$ of sun energy to electricity and have a maximum life span of one year even with encapsulation. It has been reported that OPVs have the potential to convert up to $17 \%$ of sun energy and can be fabricated by low cost roll-to-roll manufacturing methods using significantly reduced amount of raw materials [6]. This results in more economical manufacturing and also creates less environmental damage. The compatibility with roll-to-roll manufacturing has resulted in the development of a number of thin films PV technologies that aim at high profitability and low cost manufacturing. Currently, the initial cost of investment for traditional Si-PVs is around $\$ 3.20 / \mathrm{W}$, and that of OPVs is only around $\$ 2.50 / \mathrm{W}$, which enables higher cost competitiveness against conventional technology. Figs. 1 and 2 show a typical flexible organic solar cell [9].

\section{Results and Discussion}

The energy consumed and the days that the businesses were open are shown in Table 1.

The efficiency of solar cells has been increasing with the development of new materials. Technology and architectures have been developed. One of the objectives of this study is to examine the feasibility of replacing electricity generated from non-renewable fossil fuels with flexible organic solar cell. There are a number of factors effecting how much electricity can be generated from silicon solar panels on the roof and the use of flexible organic solar cells.

These include the size, number of panels, their power rating, position on the roof or available window

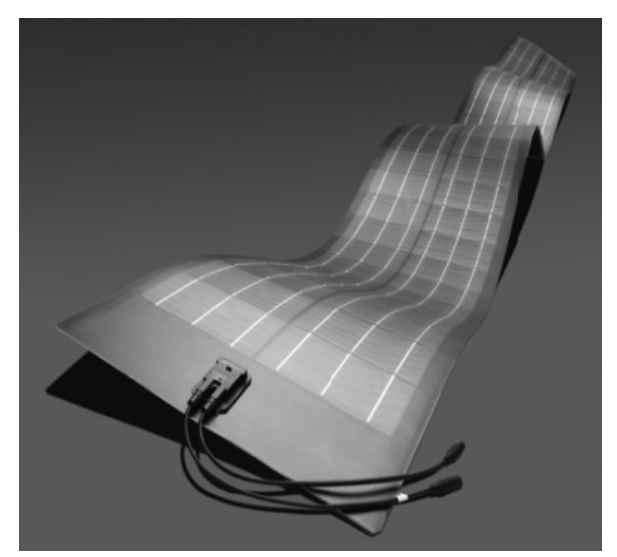

Fig. 1 Flexible organic solar cell. 


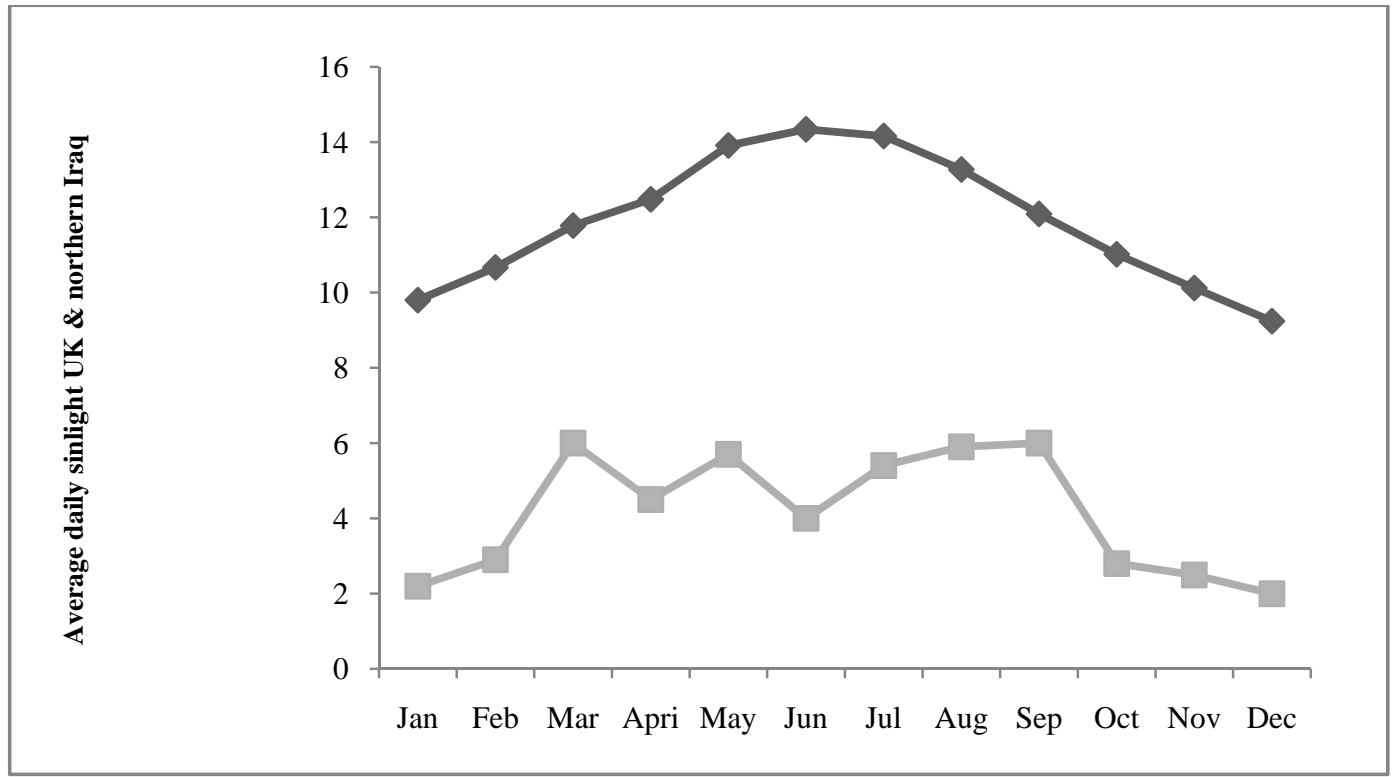

Fig. 2 Comparison between average daily sunshine in Northern Iraq with UK in 2012.

Table 1 Dayscentre was open in 2012 and electricity used.

\begin{tabular}{lcc}
\hline Month & Days open & $\begin{array}{l}\text { Units consumed } \\
(\mathrm{kWh})\end{array}$ \\
\hline Jan. & 26 & 355 \\
Feb. & 25 & 367 \\
Mar. & 27 & 532 \\
April & 25 & 574 \\
May & 27 & 461 \\
June & 26 & 426 \\
July & 26 & 427 \\
Aug. & 27 & 404 \\
Sept. & 25 & 460 \\
Oct. & 27 & 543 \\
Nov. & 26 & 416 \\
Dec. & 20 & 372 \\
Total & 307 & 5,337 \\
\hline
\end{tabular}

space and hours of sunlight. Standard production silicon solar panels generate $1,000 \mathrm{~W} / \mathrm{m}^{2}$ with an efficiency of about $15 \%-20 \%$. Hence, a $1 \mathrm{~m}^{2}$ panel produces about $150-200 \mathrm{~W}$ in good sunlight and less in cloudy and dull conditions. The efficiencies of commercial solar are expected to rise because research has already produced higher efficiency solar cells, however, this still needs to be translated to production.

To consider how much $\mathrm{CO}_{2}$ can be prevented from getting into the atmosphere and how it will impact the environment, calculations relating electricity generated to the equivalent $\mathrm{CO}_{2}$ producedwere examined. In the UK, $1 \mathrm{kWh}$ electricity generates an equivalent of 0.43 $\mathrm{kg}$ of $\mathrm{CO}_{2}$. Hence, the amount of $\mathrm{CO}_{2}$ that can be prevented from entering the atmosphere can be calculated $\left(1 \mathrm{kWh}\right.$ electricity $=0.43 \mathrm{~kg}$ of $\left.\mathrm{CO}_{2}\right)$.

Therefore, the amount of $\mathrm{CO}_{2}$ for the micro-business released onto the atmosphere per year can be calculated as: $0.43 \times 5,337 \mathrm{~kg}$ of $\mathrm{CO}_{2}=2,295 \mathrm{~kg}$.

Solar cells rely on sunlight for their operation. Hence, the average number of sunlight hours in the UK and Northern Iraq are presented in Fig. 2.

Fig. 2 shows that the number of sunlight hours fluctuates during the whole year in UK and Iraq. The average sunlight hours per day in the UK is around 4 hours, but in Iraq, it is about 10 hours. This indicates that Iraq is more conducive to the use of solar cell technology than the UK.

The expected electricity generated in kWh per day using solar panels using the Eq. (1) is:

$$
\text { Electricity }=A \times 1,000 \times \mathcal{E} \times t
$$

$\mathrm{A}$ is the area of solar panels, $\varepsilon$ is the efficiency and $\mathrm{t}$ is the hours of sunlight.

Considering a micro-business such as Blue Apple Printing, the amount of electricity that can be generated 
daily in UK and Iraq can be calculated [4]. The physical dimensions of the roof are $6 \times 2=12 \mathrm{~m}^{2}$ and about $50 \%$ of it is available for installation of silicon solar cells. Hence, an area of $6 \mathrm{~m}^{2}$ is available for solar cell installation. The amount of electricity generated in a typical day UK is: Electricity (UK) $=6 \times 1,000 \times 0.2$ $\times 4=4,800 \mathrm{Wh} /$ day $=4.8 \mathrm{kWh} /$ day.

For Kurdistan, the calculation involves longer hours of daily sunlight and the intensity of sun is much higher, hence repeating the calculation gives: Electricity (Northern Iraq) $=6 \times 1,000 \times 0.2 \times 12=14,400$ $\mathrm{Wh} /$ day $=14.4 \mathrm{kWh} /$ day.

The trend in solar cell technology is towards increased efficiency and versatile organic solar cells and mounted onto windows readily in the form of transparent thin films. Using solar cells on the windows of Blue Apple Printing, and assuming a projected efficiency of $20 \%$ from the current value of $5 \%$, the solar cells as a viable alternative to fossil fuels is highly attractive. Application of flexible solar cells to windows can provide additional electricity.

The windows on the Blue Apple Printing measure $2.1 \times 3.8=7.98 \mathrm{~m}^{2}$, which is approximately $8 \mathrm{~m}^{2}$ and therefore, two windows give an area of $16 \mathrm{~m}^{2}$. Therefore, the amount of electricity that generated with $5 \%$ efficient organic solar cells can be calculated: electricity $(\mathrm{UK})=16 \times 1,000 \times 0.05 \times 4=3,200$ $\mathrm{Wh} /$ day $=3.2 \mathrm{kWh} /$ day and electricity (Northern Iraq) $=16 \times 1,000 \times 0.05 \times 12=9,600 \mathrm{Wh} /$ day $=9.6$ $\mathrm{kWh} /$ day.

If the organic solar efficiencies were increased to $20 \%$ comparable to silicon solar cells, then these numbers increase to $12.8 \mathrm{kWh}$ and $38.4 \mathrm{kWh}$ for UK and Iraq, respectively. Hence, northern Iraq, produces 3 times more electricity per day using flexible organic solar cells. Based on UK calculations ( $0.43 \mathrm{~kg} / \mathrm{kWh})$, if a switch was made from non-renewable fossil fuels to flexible organic solar cells,the amount of $\mathrm{CO}_{2}$ reduction can be calculated. For Kurdistan-Iraq, the Mexico data $(0.52 \mathrm{~kg} / \mathrm{kWh})$ is suitable because the weather conditions are similar in the two countries.
A comparison can be made of the use of silicon solar cells to organic solar cells with 5\% and 20\% efficiencies. The corresponding reductions in harmful carbon dioxide emissions can be calculated (Table 2).

Clearly, calculations for the replacement of fossil fuels with solar cells show that the carbon emission willdecrease and reduce damage to the atmosphere. The benefits in Iraq would be much greater due to more sunlight and about 5 times the reduction in $\mathrm{CO}_{2}$ emissions compared to UK. This is also applicable to other countries in the Middle East. Hence, the use of solar cells in the Middle Eastern countries is particularly advantageous.

For the UK, the percentage of electricity generated from $20 \%$ efficient solar cells compared to fossil fuels as in Eq. (2):

$$
\begin{gathered}
\% E(\text { replaced })=\frac{E(\text { solar })}{E(\text { fossil })} \times 100 \\
=\frac{1,474}{5,337} \times 100=28 \%
\end{gathered}
$$

However, for the same business in Iraq with $20 \%$ efficient silicon solar cells and longer day light hours, the percentage of electricity needs replaced with solar cells may be calculated.

Calculations show that using the solar panel with efficiency of $20 \%$ can replace only $28 \%$ of the total electricity required to run Blue Apple Printing in the UK. The replacement of fossil fuels with solar cells will reduce the carbon emission into the atmosphere and reduce damage to the environment. However, in Iraq due to longer daily and annual daylight hours, 83\% of the energy needs with silicon solar cellscan be replaced (Table 3).

Existing flexible organic solar cells can replace 18\% and $55 \%$ in the UK and Iraq respectively. With accelerating developments in nanotechnologies particularly use of the 2D material graphene and new materials, the efficiency is expected to increase rapidly to $20 \%$ and beyond in the next few years. When the efficiency reaches 20\%, then, $74 \%$ and $220 \%$ replacement in the UK and Iraq would be possible. 
Table 2 Comparison of UK and Northern Iraq for silicon solar cells, $5 \%$ and $20 \%$ efficient organic solar cells and amount of $\mathrm{CO}_{2}$ reduction.

\begin{tabular}{|c|c|c|c|}
\hline \multirow[t]{2}{*}{ Silicon solar cell efficiency (\%) } & \multicolumn{2}{|c|}{ Organic solar cell efficiency (\%) UK (kWh) } & \multirow{2}{*}{$\begin{array}{l}\text { Northern Iraq }(\mathrm{kWh}) \\
9.6\end{array}$} \\
\hline & 5 & 3.2 & \\
\hline & 20 & 12.8 & 38.4 \\
\hline \multirow[t]{4}{*}{20} & & 4.8 & 14.4 \\
\hline & & \multicolumn{2}{|c|}{ Annual (307 days) } \\
\hline & 5 & 982 & 2947 \\
\hline & 20 & 3,930 & 11,789 \\
\hline \multirow[t]{4}{*}{20} & & 1,474 & 4,421 \\
\hline & & \multicolumn{2}{|c|}{ Annual $\mathrm{CO}_{2}$ reduction $(\mathrm{kg})$} \\
\hline & 5 & 422 & 1,533 \\
\hline & 20 & 1,690 & 6,130 \\
\hline 20 & & 634 & 2,299 \\
\hline
\end{tabular}

Table 3 Comparison of the percentage of current electricity requirements that can be replaced with solar with silicon solar cells and flexible organic solar cells.

\begin{tabular}{llc}
\hline Solar cell type & $\begin{array}{l}\text { Energy requirements replaced with solar } \\
(\mathrm{UK})(\%)\end{array}$ & $\begin{array}{l}\text { Energy requirements replaced with solar } \\
\text { (Northern Iraq) (\%) }\end{array}$ \\
\hline Silicon solar cells (20\%) & 28 & 83 \\
Flexible organic solar cells & & 55 \\
$5 \%$ & 18 & 220 \\
$20 \%$ (theoretical) & 74 & 5 \\
\hline
\end{tabular}

In the summer in Iraq, it has a requirement for cooling. The electricity for the cooling systems may come from the surplus solar energy. Hence, there will be no detriment to the environment and no need to use fossil fuel sources of electricity to run this small business. In addition, these results in $1,690 \mathrm{~kg}$ and 6,130 kg decrease in the $\mathrm{CO}_{2}$ emissions from this small business alone. The approach and methodology employed in this analysis is applicable to other microbusinesses and with millions of microbusinesses operating. There will be a major reduction in carbon emission if all the businesses could employ solar energy for their daily energy needs.

\section{Conclusions}

Micro-businesses in the UK and Iraq have been analysed and compared for energy utilization. A large proportion of fossil fuel sources can be replaced with flexible organic solar cells. Existing silicon solar cells can replace $28 \%$ and $83 \%$ of the energy requirements of the microbusiness in the UK and Northern Iraq, respectively. However, with flexible organic solar cells placed on windows with a projected $20 \%$ efficient solar cells will be able to replace $74 \%$ and $220 \%$ of the energy requirements in the UK and Iraq due to their flexibility and larger areas where they can be utilized. Using flexible organic solar cells will lower costs, and with larger areas possible, this technology can be usedwidely in Iraq. They can also be applied to other countries with similar climate.This study shows that with increasingly advanced new technology becoming available and greater efficiencies being made with solar cells, the opportunities to utilize these will provide benefit both to society and the environment.

\section{References}

[1] Griffin, P. W., Hammond, G. P., Ng, K. R., and Norman, J. B. 2012. "Impact Review of Past UK Public Industrial Energy Efficiency RD \& Amp; Dprogrammes.” Energy Conversion and Management 60: 243-250.

[2] Tsui, K. K. 2011. "More Oil, Less Democracy: Evidence from Worldwide Crude Oil Discoveries.” The Economic Journal 121: 89-115.

[3] Ross, M. L. 2001. “Does Oil Hinder Democracy?” World Politics 53: 325-361.

[4] Azabany, A., Khan, K., and Ahmed, W. 2014. "Energy 

Fossil Fuel Sources of Electricity in UK and Kurdistan, Iraq

Analysis for Replacing Fossil Fuel Energy Source of Electricity with Solar Cells in the UK and Kurdistan.” Asian Journal of Science and Technology 5 (9): 557-560.

[5] Hoppe, H., and Sariciftci, N. S. 2004. "Organic Solar Cells: An Overview.” Journal of Materials Research 19: 1924-1945.

[6] Pagliaro, M., Ciriminna, R., and Palmisano, G. 2008. “Flexible Solar Cells.” Chem. Sus. Chem. 1: 880-891.

[7] Brabec, C., Scherf, U., and Dyakonov, V. 2014. Organic
Photovoltaics: Materials, Device Physics, and Manufacturing Technologies. Weinheim: John Wiley \& Sons.

[8] Chopra, K. L., Paulson, P. D., and Dutta, V. 2004. "Thin Film Solar Cells: An Overview.” Progress in Photovoltaics: Research and Applications 12: 69-92.

[9] Al-Mohamad, A. 2004. "Solar Cells Based on Two Organic Layers.” Energy Conversion and Management 45: 2661-2665. 